\title{
CASE REPORT \\ WAARDENBURG SYNDROME TYPE I WITH IRIS AND RETINAL COLOBOMA
}

\author{
Atina Yustisia Lestari ${ }^{1}$, Reni Prastyani ${ }^{1}$ \\ ${ }^{1}$ Ophthalmology Department Airlangga University School of Medicine-Dr. Soetomo General Hospital \\ Jl. Mayjen. Prof. Dr. Moestopo No. 47 Surabaya, Indonesia
}

Corresponding author : Atina Yustisia Lestari (atina.yustisia@yahoo.com)

\begin{abstract}
We present a rare case report, Waardenberg syndrome type I, and ocular abnormalities related to the disease. A Boy, 11 months, presented with blue and hole in inferior iris. Patien also controlled to pediatric and ENT departement according his global developmental delayed, and unresponsiveness to sound stimulus since birth. Patient presented with distophia cantrorum, bilateral iris coloboma, brilliant blue iris, and retinal coloboma. Others systemic condition were skin hypopigmentation, bilateral sensorineural hearing lost, and global developmental delay equal to 6 months old baby. According to manifestations, this supporting diagnosis for Waardenberg syndrome type I. The management consists in treating the symptoms accordingly. Careful follow up and work up is important to improve patient quality of life
\end{abstract}

Keywords : Waardenberg syndrome, iris coloboma, retinal coloboma

\section{INTRODUCTION}

Waardenburg syndrome is rare genetic Abnormalities caused by absence of melanocytes in the skin, hair, eyes, and the stria vascularis of the cochlea, and classified as a disorder of neural crest cell development. The prevalance was $1 / 42.000-1 / 1.000 .000$ depend on the type of syndome. It is inherited as autosomal dominant, autosomal rececive, either sporadic (Pingault, 2010).

Waardenberg syndrome classified into four types. Clinical manifestation are hypopigmentation irish, or heterochromia, white forelock since birth or before 30 years old, dystophia canthorum, and sensory neural hearing lost. In some conditions ocular manifestation could be followed by blepharophimosis, synophrys, lagophtalmus, lacrimal mucocele, and hypopigmentation on eyelashes, choroid, and retina (Boparai, 1979; Shields, 2013). We report, 11 month old boy with characteristic feature of waardenburg syndrome type 1 along with irish and retinal coloboma.

\section{CASE REPORT}

A boy, 11 months old, non consanguineous marriage was refered to our clinic (Ophtalmology department, Soetomo General Hospital, Surabaya) from pediatric and ENT department because hypopigmentation on his both iris. In pediatric and ENT department, patient was followed up for his global developmental delayed, and sensory neural hearing lost. Family history didn't indicate same condition with patient. (Pasien adalah pasien RSUD dr soetomo, belum pernah dipublishkan sebelumnya di jurnal lain. Persetujuan ada di rekam medik rumah sakit rsud dr soetomo)

On general examination we noticed patients could not sit by his self, decreased respond to sound stimulus, and skin hypopigmentation in his neck (Figure 1). On ocular we noticed distophia cantrorum (with $\mathrm{W}$ index $=2.48$ ), bilateral iris coloboma, brilliant blue iris 
(Figure 2). His binocular refractive revealed 1 cpcm $(59 \mathrm{~cm}) / 1 \mathrm{cpd}$, similar to $6 / 180$ both eyes, streak retinoscopy was $+2.00 \mathrm{D}$ on both eyes. posterior segment examination show retinal coloboma without involvemnet optic nerve (Figure 3).

Patient had global developmental delayed, personal social equal to 7 month old, intestinal disorders, and MRI also did not show any abnormalities.

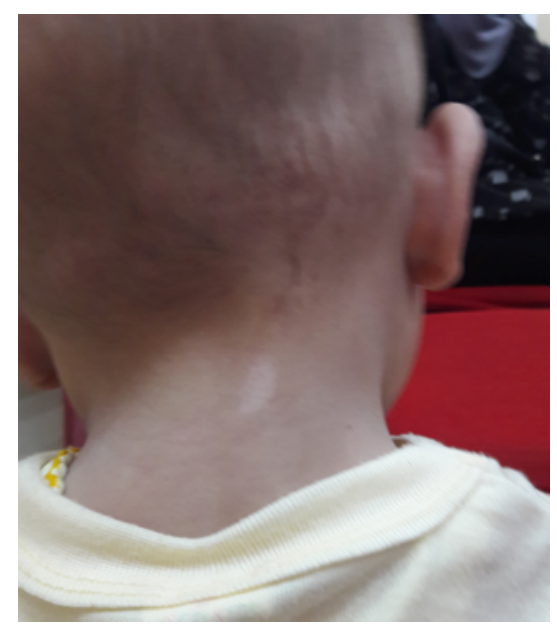

Figure 1. Skin Hypopigemntation on neck (Apakah hasil foto sendiri? IYA)

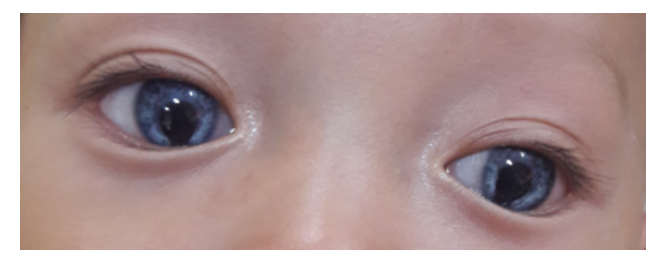

Figure 2. Distophia cantrorum with briliant blue iris and iris coloboma (Iya)

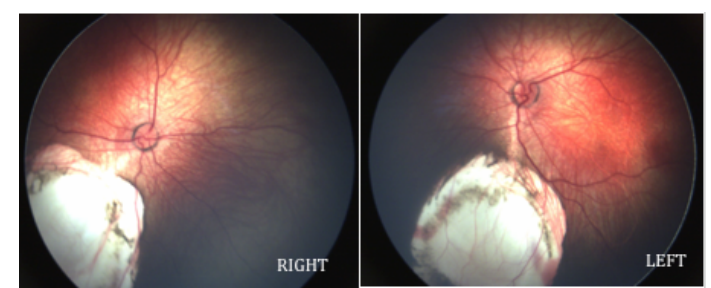

Figure 3. Retinal Coloboma (Iya) fine motoric equal to 6 months old, language equal to 6 months old, and gross motoric equal to 5 months old. Patient also performed karyotype analysis, and showed $46 \mathrm{XY}$. Audiometry examination showed sensory neural hearing lost. Patient did not have any upper limbs defect, and cranial skeletal abnormalities.

\section{Discussion}

Waardenburg syndrome is auditory pigmentary syndrome which first describe in 1947 and 1950 by Waardenburg and Klein. This genetic condition was caused by abnormal differentiated from neural crest pluripotent cell during embryogenesis. During embryogenesis, blastomere differentiated into three of layer, ectoderm, mesoderm, and endoderm. Neural system was generated from ectoderm, and developed into neural crest, and neural tube. Cell on neural tube was an origin from central neural system, including retina. Whereas, neural crest was an origin for peripheral neuron, endocrine cell, bone, cartilage, and connective tissue which are important on melanocyte synthesis. Melanocyte not only used within pigment production on skin, hair, and iris, but also it is used to regulated fluid potassium gradient between ear plasma membrane and endolymph. This fluid managed sound signal transduction on hair cell. This condition was an underlying causes on pathophysiology of the disease (Osawa, 2009).

Waardenburg syndrome classified into 4 type, manifestation of the disease depending on its type (Tabel 1). Most commont type of this syndrome were waardenburg syndrome type 1 and type 2 . Waardenburg syndrome type 1 was autosomal dominant spectrum that affacted PAX3 gene, chromosome 2, band 2q35- 2q36.1. In China population, mutation affacted on S209X gene, in Europe mutation affacted on R223S gene, others reported mutation on MIFT gene in chromosome 2, and SOX10 gene, chormosome 22. Waardenburg 
syndrome type 1 diagnosed when patient fullfill 2 major chriteria, or 1 major criteria and 2 minor criteria. Major chriteria are, sensory neural hearing lost, hypopigmentation iris, white forelock (hair hypopigmentation), and dystophia canthorum (waardernburg index > 1.95). Minor criteria are, skin hypopigmentation, broad/ high nasal root, hypoplasia alae nasi, synophyrys, and premature graying of hair (before 30 years old) (Dumayas, 2015).

Waardenburg syndrome type 2 is a condition inhereted as autosomal dominan or autosomal rececive. Main manifestation in this syndrome are congenital hearing lost, and heterochromia iris. Difference manifestation between type 1 and type 2 is absence disthopia canthorum on type 2 . Some condition follow in waardenburg syndrome type 2 are hypogonadotropine, hypogonadism, anosmia, lacrimal gland and parotis gland hypoplasia (Dumayas, 2015). Waardenburg syndrome type 3 or Klein Waardenburg syndome, could be sporadic or autosomal dominant inheritance (Pingalut, 2010). Manifestation could be follow by cleft palate, hypoplasia musculosceletal system, distrubance lower extrimities development, and joint abnormalities. Waardenburg syndrome type 3 was similar to type 1 , but in type 3 , musculosceletal deformity is present (Kniffin, 2014). Waardenburg syndrome type 4 or shah waardenburg syndrome reported as autosomal dominan or autosomal rececive. This type is the most rare condition among others type. Sometimes this type of syndrome followed by hirschprung disease, severe short stature, scoliosis, mild developmental delayed, ear formation hypoplasia, and peripheral neuropathy (Dumayas, 2015).

Genetic anomaly classified into five category, which are single gen disorder, somatic gen disorder, chromosomal disorder, mitochondrial disorder, and multifactorial. Waardenburg syndrome classified into single gene disorder. Although we could not evaluated gene disorder in this patient (because limitation on genetic analysis facilities), supporting data and examination result showed patient fullfill criteria for waardenburg syndrome type 1. Patient fullfill three major criteria, and one major criteria. One publication reported waardenburg syndrome followed by bilateral congenital cataract as unusual entitiy (Vichare and Bhargava, 2013). Coloboma iris and retina was also rare condition following the syndrome. Management consists in treating the symptoms accordingly. Patient has been followed up for his sensory neural hearing lost, and has been planned to use hearing aid. In pediatric department, patient had been stimulated for his global developmental delayed routinely. Ocular follow up was necessary to evaluate ocular manifestation according to the disease.

\section{Reference}

Boparai MS, Sohi BK, Sohi AS: Waardenburg's Syndrome. Indian $J$ Ophthalmol 1979, 27,1, 21 - 2. S.

Dumayas, Grace Lea and Aponte, E. Capo. Case Report: Waardenburg Syndrome. Military Medicine. 2015, 180, 3: 381-387.

Kniffinc:Waardenburg syndrome type3. The john shopkins university. Available At Http://Omim.Org/Entry/148820 Accessed February 13, 2014.

Osawa, M: Melanocyte Stem Cells. In: Stembook [Internet]. Cambridge, MA, Harvard Stem Cell Institute, 2009.

Pingault V, Ente D, Dastot-Le Moal F, Goossens M, Marlin S, Bondurand N: Review And Update Of Mutations Causing Waardenburg Syndrome. Hum Mutat 2010, 31,4, 391 - 406.

Vichare, Lt Col Nitin, and Bhargava, Col N. Waardenburg syndrome: A rare case with bilateral congenital cataract: An unusual entity. Medical journal armed forces india. 2013, 69,172-174. 